\title{
METHODS OF OPTIMIZING THE SUPPLY CHAIN ON THE EXAMPLE OF A SELECTED ENTERPRISE
}

doi: $\quad 10.2478 /$ czoto-2019-0077

Date of submission of the article to the Editor: 01/12/2018

Date of acceptance of the article by the Editor: 27/01/2019

Piotr Kuryło ${ }^{1}$ - orcid id: 0000-0001-9820-1254

Joanna Cyganiuk ${ }^{2}$ - orcid id: 0000-0002-7279-0692

Adam Idzikowski ${ }^{3}$ - orcid id: 0000-0003-1178-8721

Dariusz Michalski ${ }^{4}$ - orcid id: 0000-0003-3126-3041

Anna Sobczyńska-Linke ${ }^{5}$

1,2,4 University of Zielona Gora, Poland

${ }^{3}$ Czestochowa University of Technology, Poland, adam.idzikowski@wz.pcz.pl

${ }^{5}$ Noelken Sp. z o.o., Poland

Abstract: To consider the optimization of the supply chain, a company operating in the cosmetics and hygiene industry was selected. It is a typical production company with foreign capital, working on entrusted material which entirely belongs to the parent company. The company management, purchasing and sales department are located at the parent company, the Polish branch is entrusted only with production and direct distribution of finished goods. The purpose of the work is to present the applied logistic solutions, characterize and analyse the existing supply chain and to propose actions to optimize currently used methods.

Keywords: logistics network, supply chain, optimization

\section{INTRODUCTION}

The analysed company is a Polish branch of a German manufacturer operating in the hygiene industry. The company produces hygienic articles such as: moisturized toilet paper, wet wipes for babies and children, etc.

The company's operations in Poland consist in the processing of materials and raw materials entrusted by the parent company, so that a fully-fledged finished product is produced. These products are then transferred to the principal, i.e. the parent company, and the Company's revenue comes from the inward processing service. The clients of the parent company are mainly trade networks from Germany, the Netherlands, Belgium, France, Great Britain, Sweden, Russia, the Czech Republic and Hungary.

The analysed company is a typical production plant. The sales department, the purchase department, the material supply department and the research and development are located in the parent company. All decisions regarding the profile of the manufactured assortment, used raw materials and applied technological solutions 
are taken at the head office of the parent company, and they are submitted to the Plant in the form of a regulation.

\section{PRODUCTION SPECIFICATION}

The production process takes place in a production hall divided into two zones a wet one and a dry one. Wet production, including the production of moisturized products, is carried out with the use of 6 production lines. Production of lactation pads, called dry production, takes place on 2 production lines. The production cycle itself is very short. Depending on the line, the currently used technology allows to manufacture from 20,000. up to 130,000 individual items in a single production shift.

The main raw materials used in production processes are:

- a non-woven fabric made of polypropylene (or a mixture of polypropylene and polyester),

- cellulose pulp

- a mixture of diluted liquid for moisturising the non-woven webs

- PET or OPP / PE film

- complementary raw materials such as: labels, cartons, collective cartons, covers closing packages, suction cups, etc.

The client (parent company) is responsible for the selection of suppliers and material disposition. The tasks of the Polish branch include the inspection of all the raw materials supplied, the control of the timeliness of deliveries, execution of individual production orders and the delivery of finished products in accordance with the ordered date (Own study).

\section{CONSTRUCTION OF THE SUPPLY CHAIN}

\subsection{Logistics of finished products}

Logistics is one of the most important activities of each company (Liberko, I.,Bednarova, Hajduova, et al., 2105). At the beginning of the discussed company's activity, all manufactured products were transported to the headquarters of the parent company in Germany, and then they were distributed to the recipient. Along with the development of the company, direct mailing was introduced. Currently, $70 \%$ of production goes to two external warehouses, then, after the goods have been ordered, they are delivered directly to the customer, $20 \%$ is sent straight to the ordering party, and $10 \%$ is transported to the parent company, where the goods are completed with other products and then sent off. The Polish branch has its own warehouse with an area of 2,500 m2, including 1,800 rack spaces. The warehouse is divided into a storage zone of raw materials (in high storage racks) and in blocks intended for bale storage (fleece), and a finished goods warehouse, in which space for quarantined products has been separated. With the increase in production, the Management Board decided to launch additional storage areas (including an additional 3,500 rack spaces) in two forwarding services located close to the national border.

Currently, the Polish branch cooperates with four forwarding companies. Forwarding Wackler is responsible for the delivery of groupage orders outside the country. The transport of groupage shipments inside the country was entrusted to RABEN. Handling of full-truck shipments (direct and indirect) takes place with the participation of Drewtrans and Goettlich forwarding. Both in the Polish branch and in the parent 
company in Germany, there is one common ERP system that is adapted to the business profile. It is an integrated system supporting the management of the production department, planning - material disposal, warehouse, purchasing and quality. For the needs of the main company, a financial panel was also added, the Polish branch is supported in this area by additional IT programs.

\subsection{The flow of raw materials - material dispos}

The customer service, purchasing and material disposal department is located at the head office, also the production plan covering the production lines in the Polish branch is formulated in the parent company. The plant receives production orders included in a three-month production plan. Control over the implementation of the plan, verification of raw materials and their availability is performed by the production planning manager. This person is also responsible for the settlement of used materials and the appropriate response in case of unplanned downtime. This person's duty is also checking if any short-term (unplanned) orders are possible to be realised as well as the confirmation of such orders.

The production plan is built based on the forecast of standing orders as well as the socalled orders with deadline confirmation (production on order). Based on the order history and sales plans of regular customers, a production plan is built. The plan assumes the storage of the amount of goods equal the triple standard customer order - depending on whether it is a category A, B or C customer. The stored inventory can be reduced to two or one standard order level. Due to the short production cycle and the fact that the offered products belong to FMCG products, the standard quantity of the order is usually the quantity ordered within one month. This rough plan is completed with custom orders from smaller customers who do not make regular purchases. These customers accept a longer delivery deadline, instead they do not have to specify exact purchase plans or do not involve a longer contract with the supplier. They are mainly trading agents.

As mentioned above, the designated person performs control over the implementation of the production plan. This person is also in charge of resolving problems with the implementation of an order, which are most often caused by a sudden failure of the production line. Depending on the time spent removing the failure, the planning manager checks the possibility of moving the order or shortening it and adjusts subsequent orders to the current situation.

When the production order is generated in the system, the disposition department is responsible for ordering the relevant raw materials. Due to the considerable waiting time for individual components, it is necessary to forecast production orders at least 3 months in advance. In the case of any delays of individual orders, the disposition department also takes care of the appropriate shift of deliveries and protects the warehouse against excessive collection of raw materials.

During more than thirty years of operation, the analyzed company has created an integrated delivery system with the majority of its suppliers and customers (Hałas, 2014). Thanks to the applied IT systems allowing for the same marking and identification of goods, mutual information about the state of their stocks, deadlines for new orders, order history and expectations for subsequent projects, the network of links between suppliers, customers and the manufacturer is strong and based largely on mutual trust (and of course secured by appropriate agreements). This solution is quite innovative (especially in relation to the Polish market), but allows an uninterrupted 
production sequence at individual links in the chain, joint coordination of individual flows and their cultural compatibility (Rutkowski, 1999).

The following participants can be distinguished in the whole supply chain:

- system suppliers (receiving orders when the manufacturer's production order is confirmed): main suppliers of non-woven fabric, heat-shrinkable film, collective packaging;

- producer;

- recipients of finished products: retail chains with their own brand, trade concerns with many own brands, and distributors of their own brand, e.g. Noelken Babyline, BarbaraN, Pikobelo;

- forwarding companies and operators of external warehouses.

\subsection{SWOT analysis of the identified supply chain}

The existing dependencies between individual links in the chain, and above all, the long-term cooperation and functioning of the network of mutual connections, allow to analyze the advantages and disadvantages of the existing system as well as to identify its opportunities and threats (Khatri, Metri, 2016). Due to the total dependence on the parent company in the selection of suppliers, the SWOT analysis (Table 1 and 2) refers to the company in the scope of the entire range of manufactured products throughout Europe, and not only to the Polish branch (Own study).

Table 1

SWOT analysis - strengths and weaknesses of the functioning supply chain

\begin{tabular}{|c|c|}
\hline Strengths & Weaknesses \\
\hline $\begin{array}{ll}\text { - } & \text { predictability of production } \\
\text { - } & \text { JIT delivery } \\
\text { - } & \text { recipes relatively easy to be modified } \\
& \text { thanks to fast reacting suppliers } \\
\text { - } & \text { short time of storage of main stocks, place- } \\
\text { consuming raw materials } \\
\text { - } \text { the use of international, commonly used } \\
\text { SSCC codes } \\
\text { - } \text { punctuality of deliveries allowing timely } \\
\text { execution of orders } \\
\text { - } \text { applying uniform standards in the area } \\
\text { of management, control of the } \\
\text { production process and selection of } \\
\text { suppliers / subcontractors } \\
\text { - thanks to various forwarding partners, } \\
\text { delivery guarantee within } 72 \text { hours } \\
\text { from the moment of order placing (for } \\
\text { planned orders) } \\
\text { - cooperation with international suppliers } \\
\text { favours establishing contacts with } \\
\text { potential clients }\end{array}$ & $\begin{array}{l}\text { - the necessity to receipt (and pay) supplies } \\
\text { of raw materials for interrupted projects } \\
\text { (high costs of destruction of raw materials } \\
\text { not used - refers mainly individual shrink } \\
\text { films) } \\
\text { - } \text { a relatively large amount of stocks of } \\
\text { finished products } \\
\text { - the wide assortment makes it necessary to } \\
\text { maintain numerous small stocks of raw } \\
\text { materials at a minimum amount (which } \\
\text { occupy a significant part of the warehouse } \\
\text { space, though) } \\
\text { - the wide range requires numerous } \\
\text { retoolings of the production lines - possible } \\
\text { failures caused during retoolings disrupt } \\
\text { the entire chain } \\
\text { - frequent reloading from external } \\
\text { warehouses to the recipient's cross- } \\
\text { docking stores cause that the target } \\
\text { customer receives goods with visible } \\
\text { damages caused during transport / } \\
\text { reloading (refers products with a total } \\
\text { weight of over } 500 \text { kg/pal) } \\
\text { - failure to fulfil the order by the supplier } \\
\text { results in the need to reconstruct the } \\
\text { production plan, may affect the }\end{array}$ \\
\hline
\end{tabular}




\begin{tabular}{|l|l|}
\hline Strengths & \multicolumn{1}{|c|}{ Weaknesses } \\
\hline & $\begin{array}{l}\text { implementation of the order by the } \\
\text { manufacturer and may weakens its } \\
\text { competitive position }\end{array}$ \\
& \\
\hline
\end{tabular}

Table 2

SWOT analysis - threats and opportunities of the functioning supply chain

\begin{tabular}{|c|c|}
\hline Opportunities & Threats \\
\hline $\begin{array}{l}\text { - } \text { the possibility of combining deliveries } \\
\text { together with receipts of goods in one } \\
\text { car (cooperation of forwarding } \\
\text { companies) } \\
\text { - } \text { unified IT system (mainly through the } \\
\text { Transporeo platform) at all links in the } \\
\text { chain leads to better coordination of } \\
\text { loading and unloading and to the } \\
\text { development of an efficient notification } \\
\text { system for individual loads. }\end{array}$ & $\begin{array}{l}\text { - may affect the realisation of the order by } \\
\text { the manufacturer and thus afflict its } \\
\text { competitive position } \\
\text { - lack of supervision over the physical } \\
\text { condition of inventories in external } \\
\text { warehouses (in } 2013 \text {, there were } 4 \text { internal } \\
\text { complaints regarding damage / inventory } \\
\text { damages in an external warehouse) } \\
\text { - high employee turnover in external } \\
\text { warehouses may cause numerous errors in } \\
\text { the system records }\end{array}$ \\
\hline
\end{tabular}

\section{BASE CONCEPT OF THE SUPPLY CHAIN - PLANNING THE SUPPLY CHAIN DOSTAW}

In typically manufacturing companies, such as the analysed enterprise, the basic type of production determines the shape of the entire supply chain. It should be noted that the more diverse the product is manufactured and the wider the assortment, the more complex the problems that must be faced when constructing the supply chain. It is also influenced by geographical reach and the number of recipient segments. The more and the more diverse the segments, the greater the need to include more links forming the logistics network.

Network building is based primarily on the analysis of the following information:

- the number and specification of products of a production line

- the size and structure of supply of each of the products at customer locations,

- location of outlets and sources of raw materials,

- transport cost, freight rates,

- storage costs and rates for storage space,

- supply costs and production costs

- frequency of deliveries (Krawczyk, 2001).

Having analysed the data, it is also necessary to predict such factors as:

- planned expansion into new markets,

- shifts of customer clusters,

- predicted extension of the offered assortment,

- the possibility of appearance of the competition (and the degree of the threat),

- political and economic factors stimulating investments (Kramarz, 2014).

The network built on the basis of the above data has a significant impact on the level of logistic customer service, i.e. the time and cost of the order. Thanks to the detailed analysis of the above factors, it is possible to determine the lowest possible costs of 
the location of production and/or warehouses, taking into account the places of obtaining raw materials, as well as determining the distribution places of the products. When configuring an effective logistics network, the decisions regarding the product storage, affecting the company's activity in the long term, are analyzed separately. The choice between investing in the own finished product warehouse and renting warehouse space requires the determination and valuation of all advantages and disadvantages of a given solution. The benefits of owning warehouses include, first of all, control over the product, the ability to quickly respond to changing customer requirements, full information on the status of inventory and product flows, keeping an informed policy of keeping stocks and bearing the risk and liability resulting from it. On the other hand, however, there are considerable costs of maintaining the facility and its service, costs of maintaining the communication infrastructure, as well as the cost of lost production investments (expenditures incured on the own warehouse could be allocated for production development) (Libiszewska, 2014).

Summarizing, the strategy of building a logistics network must support the overall strategy of the organization (Liberko, I.,Bednarova, Hajduova, et al., 2105). An efficient supply chain affects the development of production capacity, achieving a competitive advantage of the company, the quality of manufactured products and the quality of customer service.

\section{SELECTED METHODS OF OPTIMIZATION OF A SUPPLY CHAIN ON THE EXAMPLE OF THE ANALYSED ENTERPRISE}

In the plants of the analysed enterprise, located throughout Europe, trials were repeatedly undertaken to introduce the Lean concept. The main reasons for these changes were the desire to streamline the production process and the developed logistics network including suppliers and recipients. As a result, the Management Board adopted a strategy for dividing production into standing and short-batch orders. Standing orders are carried out by the German branch, and short-batch orders in Poland. In addition, the Polish branch was entrusted with the entire dry production requiring the construction of a network of separate suppliers (for the wet production, the raw materials are supplied by the same suppliers to both branches). The only department that successfully managed to successfully implement the lean management system is the purchasing department. Most deliveries are carried out according to the JIT rule, and strategic suppliers (mainly the non-woven suppliers) have developed a system of actions in case of emergency events such as delay caused by failure of production lines, poor road conditions, etc. Once a year, suppliers are audited, and each new project, such as the renovation or purchase of a production line, product change, etc., are among the first to be informed about it. The close cooperation between the quality departments of individual suppliers and the quality department of all plants was also developed. The vast majority of stocks of raw materials consists of raw materials for non-standard, rare production, carried out in very short series, resulting from a very wide range of products. The system of notification of individual deliveries needs to be improved so that the unloading windows can be arranged. So far in the Polish branch, it has been possible only with three suppliers, the remaining ones are subject to notification for a specific day (without a fixed unloading time). In German branches, the deliveries are planed until 10 am and from 2 to $6 \mathrm{pm}$; receipts of goods take place between. $10-14$ and 14-17 for groupage shipments. Thanks to these arrangements, work in the warehouse runs in a fixed, repetitive rhythm. In order to 
better coordinate deliveries and receipts, the company should go towards IT solutions, especially as the ERP (Citrix) system used allows generating orders with a specific day and delivery time, and automatically sends them to a specific partner. At least two days before delivery, it is possible to send information confirming the specific booking time of the unloading ramp for a given delivery.

With reference to production, the lean concept is difficult to implement, especially in the Polish branch. This is mainly due to the fact that this branch is entrusted with short-term orders, which is connected with the necessity of numerous retoolings of production lines.

The wide assortment and short production series also contribute to the problems of production switching; depending on the type of product and its components, the time allowed for changing the manufactured product is from 30 minutes to even 8 hours, and often, despite its relative repetition, it varies (since it depends mainly on the operator's skills). All these problems contribute to the emergence of numerous sources of wastage of raw materials and working time. The maintenance department uses the OEE analysis (overall equipment efficiently), thanks to which it is possible to determine the cause of the most frequent stoppages and to prepare technical support (tools and stocking) for operators generating the longest series start times.

The department that is still unable to implement the lean concept is the sales department. Because $80 \%$ of the production of both companies is produced for stock based on customers' purchase plans and the history of their orders, effective communication with recipients and their execution of the submitted plans determines the possibilities of searching for places still requiring the introduction of the lean concept. The high level of inventories of finished products as well as the relative frequency of changes in the production plan clearly show that the recipients use their advantage and do not follow the arrangements. Due to the fact that the company guarantees delivery within 72 hours on receipt of the order (excluding production on order) it is necessary that the information provided from the recipients be as reliable as possible and allow the development of a stable production rhythm (ADD ratio, average demand of the customer and customer's tact). The production planning department together with the sales department should constantly analyse the results obtained, and the occurring deviations should be discussed with the recipient on an ongoing basis. It is also necessary to change the policy of maintaining inventories. At present, 24 months are assumed for the maximum storage time for finished goods. After this time, the products are destroyed and recorded as losses. Once a quarter, the logistics manager in the Polish branch presents the inventory rotation ratio in days and indicates the items for which the level of inventory has exceeded the allowable size. Annual reviews of raw materials and the level of their use lead to the separation of unused raw materials. This usually results in a decision to destroy them (annually it is from 10,000 to even 100,000 euro). The level of destruction clearly indicates communication problems with some recipients.

The logistics department should also improve internal transport (analysis of communication routes, especially in terms of eliminating bottlenecks at the collision points, i.e. where raw materials for production are issued and the production returns are accepted). The solution may be to establish places (next to production lines) for raw materials which are consumed quickly. It is also necessary to introduce a time notification for all deliveries and receipts of goods. However, the highest level of stock of finished products requires the highest concentration. Support for the existing 
warehouse panel in a functioning system through developed and compatible WMS systems would allow to increase process efficiency, reduce stock levels by quickly identifying overdue goods and reduce the risk of overdue raw materials (especially ready-made mixtures and concentrates) (WMS survey, 2012). All these steps will significantly reduce logistics costs.

\section{CONCLUSIONS}

When looking for opportunities to optimize the supply chain, cost-effectiveness should be strived for (Zhang, 2017), while maintaining high flexibility and taking into account micro- and macro-environmental factors. This requires the implementation (from the beginnings) and/or the streamlining of the processes related to: purchasing policy, material disposition, sales and production through: defining clear delivery rules, the method they are settled and the consequences of failing to meet deadlines and/or of discordant shipments; realisation of deliveries according to JIT and JIS (Just in Sequence) rules; forecasting the demand for a product and raw material based on information from recipients and on the results of internal analyses from fully used ERP and / or WMS systems, optimization of raw material and finished product inventory levels, improvement of material and product rotation; standardization of work, as well as efficient results management. All these operations translate into an increase in activities that create added value for the recipient and eliminate sources of waste.

\section{REFERENCESE}

Escobar, J., 2016. Supply chain optimization with variable demand by considering financial criteria and scenarios. Revista Facultad de Ingeniería, 26/44, 21-32.

Gołembska, E., 2010. Kompendium wiedzy o logistyce. Wydaw. Nauk. PWN, Warszawa.

Guo, B. L., 2015. The Research of Supply Chain Optimization Theory Based on Service-Oriented Manufacturing. Applied Mechanics and Materials, 733, 964-967.

Hałas, E., 2014. Zarządzanie łańcuchem dostaw w oparciu o standardy EAN - UCC. Instytut Logistyki i Magazynowania., www.ean.pl [18-03-2014].

Jurczak, M., 2011. Produkcja w logistyce czy logistyka w produkcji. Logistyka a jakość, 5, 58-60.

Khatri, J., Metri, B., 2016. SWOT-AHP Approach for Sustainable Manufacturing Strategy Selection: A Case of Indian SME.GLOBAL BUSINESS REVIEW, 17, 5, 1211-1226.

Kramarz, M., 2014. Analiza otoczenia łańcucha dostaw jako etap złożonego systemu logistycznego na przykładzie branży farmaceutycznej. LogForum. Elektr., http://www.logforum.net/vol5/issue4/no5 [22-05-2014].

Krawczyk, S.,: 2001. Zarządzanie procesami logistycznymi. PWE, Warszawa.

Liberko, I., Bednarova, L., Hajduova, Z., et al. 2105. Possibilities to optimize the logistics chain in the manufacturing plant. Polish Journal Of Management Studies, 12, 2, 103-113.

Libiszewska, M., 2014. Wytwarzanie wartości dodanej bez marnotrawstwa. Logistyka a jakość, 3/12,54-55 .

Ogólnopolskie badanie użytkowników systemów WMS 2012. 2012. Appendix in Logistyka a jakość, 4.

Rutkowski, K., 1999. Zintegrowany łańcuch dostaw. Doświadczenia globalne i polskie. Szkoła Głowna Handlowa, Warszawa. 
Siarkiewicz, A., 2013. Odpowiedzialna strategia - odpowiedzialne zarządzanie łańcuchem dostaw. Logistyka a jakość, 14/4, 46-48.

Vonau, P., 2012. Zarzadzanie łańcuchem dostaw -optymalizacja kosztów czy coś więcej. Strategy Consultants. http://logistyka.wnp.pl/ [13-02-2012].

Zhang W., 2017. Enterprise Logistics Analysis based on Supply Chain Optimization. International Conference On Intelligent Transportation, Big Data \& Smart City (ICITBS), 357-360. 